\title{
Analisis Rasionalitas Penggunaan Antipsikotik Pada Pasien Skizofrenia Di Instalasi Rawat Inap RSJD Atma Husada Mahakam Samarinda Tahun 2016
}

\section{Rationality of Antipsicotic Use in Hospitalized Skizofrenia Patients in RSJD Atma Husada Mahakam Samarinda 2016}

\author{
Rika Paramitha S, Elina Endang S, dan Meta Kartika U \\ ${ }^{*}$ Fakultas Farmasi Universitas Setia Budi, Surakarta \\ Jln. Letjen Sutoyo-Mojosongo Surakarta-57127 Telp. 0271-852578 \\ *Email: rikha.paramithas@gmail.com
}

\begin{abstract}
Abstrak
Skizofrenia adalah sindrom heterogen kronis yang ditandai dengan pola pikir yang tidak teratur, delusi, halusinasi, perubahan perilaku yang tidak tepat, serta adanya gangguan fungsi psikososial. Tujuan penelitian ini untuk mengetahui pola penggunaan antipsikotik serta rasionalitas penggunaan antipsikotik pada pasien skizofrenia di Instalasi Rawat Inap RSJD Atma Husada Mahakam Samarinda tahun 2016 berdasarkan tepat indikasi, tepat pemilihan obat, tepat pasien, dan tepat dosis. Penelitian ini menggunakan metode deskriptif non eksperimental dengan pengambilan data secara retrospektif dari rekam medik pasien dengan teknik sampling purposive sampling. Sampel yang digunakan adalah 94 pasien yang mendapatkan antipsikotik dengan rentang usia 17-55 tahun dan memiliki riwayat pengobatan yang lengkap. Data yang diperoleh dianalisis kerasionalannya berdasarkan Guideline Texas Medication Algorithm Project Procedural Manual Schizophrenia Treatment Algorithms. Berdasarkan hasil penelitian diperoleh data penggunaan antipsikotik tunggal yang paling banyak digunakan adalah haloperidol sebanyak 39 resep $(53,42 \%)$. Penggunaan kombinasi dua antipsikotik yang paling banyak diresepkan yaitu kombinasi antara clozapine-haloperidol sebanyak 19 resep (38,00\%), sedangkan kombinasi tiga antipsikotik yang diresepkan yaitu kombinasi antara chlorpromazine-risperidone-clozapine dan haloperidol-risperidone-clozapine masing-masing sebanyak 1 resep $(50,00 \%)$. Kerasionalan penggunaan antipsikotik diperoleh persentase tepat indikasi sebesar $100,00 \%$, tepat pemilihan obat $95,20 \%$, tepat pasien $100,00 \%$, dan tepat dosis $100,00 \%$.
\end{abstract}

Kata kunci: skizofrenia, antipsikotik, rasionalitas

\begin{abstract}
Schizophrenia is a chronic heterogeneous syndrome characterized by irregular mindset, delusion, hallucination, improper behavioral changes, and psychosocial dysfunction. The purpose of this research was to know the pattern of antipsychotic use and rationality of antipsychotic use in schizophrenia patient at Inpatient Installation of Atma Husada Mahakam Psychiatric Hospital Samarinda in 2016 based on right indication, right drug selection, right patient, and right dose. The study was use descriptive nonexperimental method with retrospective data collection from medical record of patients with purposive sampling technique. The samples used was 94 patients who received antipsychotic with age range 17-55 years and had a complete medical history. The data obtained were analyzed according to Guideline Texas Medication Algorithm Project Procedural Manual of Schizophrenia Treatment Algorithms. Based on the results obtained data of single antipsychotic the most widely used was haloperidol as 39 prescriptions $(53.42 \%)$. The use of the most commonly prescribed combination of two antipsychotic was combination of clozapine-haloperidol as 19 prescriptions (38,00\%), while combination of three prescribed antipsychotic was combination of chlorpromazine-risperidone-clozapine and haloperidol-risperidone-clozapine each as 1 prescription (50,00\%). The rationale of antipsychotic use obtained percentage of right indication was $100 \%$, right drug selection 95,20\%, right patient 100\%, and right dose $100 \%$.
\end{abstract}

Keywords: schizophrenia, antipsychotic, rationality. 


\section{PENDAHULUAN}

Skizofrenia adalah sindrom heterogen kronis yang ditandai dengan pola pikir yang tidak teratur, delusi, halusinasi, perubahan perilaku yang tidak tepat serta adanya gangguan fungsi psikososial. (DiPiro et al 2015). Skizofrenia biasanya menyerang pasien berusia 15-35 tahun. Diperkirakan terdapat 50 juta penderita di dunia, 50\% diantaranya tidak mendapatkan pengobatan yang sesuai dan $90 \%$ dari penderita yang tidak mendapatkan pengobatan yang sesuai tersebut terjadi di negara berkembang (WHO 2011). Data Riskesdas (2013) menunjukkan prevalensi gangguan mental emosional yang ditunjukkan dengan gejala-gejala depresi dan kecemasan untuk usia 15 tahun keatas mencapai sekitar 14 juta orang atau $6 \%$ dari jumlah penduduk Indonesia. Sedangkan prevalensi gangguan jiwa berat seperti skizofrenia mencapai sekitar 400.000 orang atau sebanyak 1,7 per 1.000 penduduk.

Rasionalitas obat

(ketepatan pengobatan) adalah pemakaian obat yang rasional dimana pasien menerima pengobatan yang sesuai dengan kebutuhan klinis. Penggunaan suatu obat dikatakan tidak rasional jika kemungkinan dampak negatif yang diterima oleh pasien lebih besar dibanding manfaatnya (Kemenkes RI 2011). Menurut British Medical Association (BMA) obat yang paling sering dan umum digunakan untuk terapi skizofrenia adalah antipsikotik. Obat antipsikotik dapat digunakan utnuk terapi skizofrenia dengan gejala halusinasi, delusi dan untuk pencegahan keterulangan (BMA 2009). Tujuan dari penelitian ini adalah untuk mengetahui rasionalitas penggunaan antipsikotik yang meliputi tepat indikasi penyakit, tepat pemilihan obat, tepat pasien, dan tepat dosis pada pengobatan pasien skizofrenia di Instalasi Rawat Inap RSJD Atma Husada Mahakam Samarinda tahun 2016 berdasarkan Guideline Texas Medication Algorithm Project Procedural Manual Schizophrenia Treatment Algorithms.

\section{METODE PENELITIAN}

Penelitian ini dilakukan dengan rancangan deskriptif non eksprimental yang bersifat eksploratif dengan pengumpulan data kualitatif secara retrospektif. Data rekam medik ini diambil dari RSJD Atma Husada Mahakam Samarinda. Informasi yang ada pada rekam medis dicatat pada form pengumpulan data yang telah dibuat. Sampel penelitian yang digunakan adalah data rekam medik pasien yang didiagnosis skizofrenia di instalasi rawat inap RSJD Atma Husada Mahakam Samarinda mulai dari tanggal 1 Januari hingga 31 Desember 2016 yang memenuhi kriteria inklusi.

\section{HASIL DAN PEMBAHASAN}

Penelitian pada tahun 2016 terdapat 517 pasien yang dirawat di RSJD Atma Husada Mahakam Samarinda, tetapi hanya 94 pasien yang memenuhi kriteria inklusi. 423 pasien lainnya termasuk kriteria ekslusi diantaranya pasien terdiagnosa penyakit lain, pasien meninggal, dan pasien dengan data rekam medik yang tidak lengkap, rusak, atau hilang.

Data tersebut meliputi: jenis kelamin, usia, diagnosa dan jenis obat.

Tabel 1 menunjukkan bahwa jumlah pasien skizofrenia dengan jenis kelamin lakilaki jumlahnya hampir tiga kali lebih banyak bila dibandingkan pasien skizofrenia dengan jenis kelamin perempuan. Secara garis besar, perbedaan yang terjadi dari segi jenis kelamin pada pasien skizofrenia di Instalasi Rawat Inap RSJD Atma Husada Mahakam Samarinda selama tahun 2016 terlihat signifikan karena laki-laki secara sosial merupakan penopang utama dalam keluarga dan memiliki tekanan hidup yang lebih besar dibandingkan perempuan sehingga dapat memicu terjadinya stres (Hariyani et al 2015). Adanya efek perlindungan (neuroprotektif) dari hormon estrogen secara tidak langsung akan mempengaruhi kemunduran onset dan perjalanan penyakit skizofrenia yang lebih baik pada wanita (Mueser \& Dilip 2008). 
Tabel 1. Persentase pasien skizofrenia berdasarkan jenis kelamin, usia, dan jenis skizofrenia di Instalasi Rawat Inap RSJD Atma Husada Mahakam Samarinda tahun 2016

\begin{tabular}{|c|c|c|c|}
\hline \multicolumn{2}{|r|}{ Kriteria } & Jumlah pasien/kasus & Persentase (\%) \\
\hline \multirow{2}{*}{ Jenis kelamin } & Laki-laki & 69 & 73,40 \\
\hline & Perempuan & 25 & 26,60 \\
\hline & Total: & 94 & 100 \\
\hline \multirow{4}{*}{ Usia } & $17-25$ & 20 & 21,28 \\
\hline & $26-35$ & 34 & 36,17 \\
\hline & $36-45$ & 29 & 30,85 \\
\hline & $46-55$ & 11 & 11,70 \\
\hline \multicolumn{2}{|r|}{ Total: } & 94 & 100 \\
\hline \multirow{4}{*}{$\begin{array}{c}\text { Jenis } \\
\text { skizofrenia }\end{array}$} & Skizofrenia paranoid & 33 & 35,11 \\
\hline & Skizofrenia hebefrenik & 4 & 4,26 \\
\hline & Skizofrenia tak terinci & 57 & 60,64 \\
\hline & Total: & 94 & 100 \\
\hline
\end{tabular}

Sumber: Data sekunder yang telah diolah (2017).

Hormon oksitosin pada perempuan juga dapat mengurangi gejala psikosis dengan menghambat dopamin di mesolimbik dan memperbaiki pola pikir serta persepsi sosial (Seeman 2004).

Data yang diperoleh menunjukkan bahwa pasien skizofrenia di Instalasi Rawat Inap RSJD Atma Husada Mahakam Samarinda pada tahun 2016 berdasarkan pengelompokkan usia, insidensi terbanyak terjadi pada rentang usia 26-35 tahun karena skizofrenia biasanya menyerang pasien yang berusia 15-35 tahun (WHO 2011). Skizofrenia paling sering terjadi pada akhir masa remaja atau dewasa awal dan jarang terjadi sebelum masa remaja atau setelah usia 40 tahun dikarenakan rentang usia tersebut merupakan usia produktif yang dipenuhi dengan banyak faktor pencetus stress dan memiliki beban tanggungjawab yang besar (DiPiro et al 2015).

Data yang diperoleh menunjukkan bahwa jenis diagnosa skizofrenia terbanyak yang terdapat di Instalasi Rawat Inap RSJD Atma Husada Mahakam Samarinda pada tahun 2016 adalah skizofrenia tak terinci. Skizofrenia tak terinci merupakan sejenis skizofrenia dimana gejala-gejala yang muncul sulit untuk digolongkan pada tipe skizofrenia tertentu (Arif 2006). Hanya gambaran klinisnya terdapat waham, halusinasi, serta inkoherensi atau tingkah laku yang kacau (Hawari 2014).

Tabel 2 menunjukkan bahwa penggunaan antipsikotik tipikal atau generasi pertama adalah yang terbanyak diresepkan di RSJD Atma Husada Mahakam Samarinda pada tahun 2016 karena antipsikotik tipikal bekerja dengan cara menurunkan hiperaktivitas dopamin dijalur mesolimbik, sehingga menyebabkan gejala positif menurun. Keuntungan penggunaan antipsikotik tipikal adalah jarang menyebabkan terjadinya SNM (Sindrom Neuroleptik Malignant) dan cepat menurunkan gejala positif. Kelemahan dari

Tabel 2. Persentase penggunaan antipsikotik berdasarkan golongannya di Instalasi Rawat Inap RSJD Atma Husada Mahakam Samarinda tahun 2016

\begin{tabular}{ccc}
\hline Kategori Golongan Antipsikotik & Jumlah Resep & Persentase (\%) \\
\hline Tipikal & 48 & 47,52 \\
Atipikal & 25 & 24,75 \\
Tipikal-Atipikal & 28 & 27,72 \\
\hline Total: & $\mathbf{1 0 1}$ & $\mathbf{1 0 0 , 0 0}$
\end{tabular}

Sumber: Data sekunder yang telah diolah (2018). 
Tabel 3. Persentase penggunaan ajuvan berdasarkan kelas terapi di Instalasi Rawat Inap RSJD Atma Husada Mahakam Samarinda tahun 2016

\begin{tabular}{llcc}
\hline \multicolumn{1}{c}{ Kelas Terapi } & \multicolumn{1}{c}{ Nama Obat } & $\begin{array}{c}\text { Jumlah } \\
\text { Resep }\end{array}$ & $\begin{array}{c}\text { Persentase } \\
(\boldsymbol{\%})\end{array}$ \\
\hline \multirow{2}{*}{ Anti Parkinson } & Difenhidramin (Inj. Delladryl) & 6 & 6,06 \\
& Triheksifenidil (THD/Hexymer) & 52 & 52,53 \\
\hline \multirow{2}{*}{ Anti Ansietas } & Diazepam & 25 & 25,25 \\
& Lorazepam (Merlopam) & 4 & 4,04 \\
\hline \multirow{2}{*}{ Antidepresan } & Kalsetin/Elizac & 2 & 2,02 \\
& Sertraline & 2 & 2,02 \\
\hline \multirow{2}{*}{ Antasida (Anti Ulkus) } & Antasida & 1 & 1,01 \\
& Ranitidin & 3 & 3,03 \\
\hline \multirow{2}{*}{ Anti Alergi (Anafilaksis) } & Cetirizin & 1 & 1,01 \\
& LTM & 1 & 1,01 \\
\hline Total: & Loratadin & 2 & 2,02 \\
\hline Sumber: Data sekunder yang telah diolah (2018). & $\mathbf{9 9}$ & $\mathbf{1 0 0 , 0 0}$ \\
\hline
\end{tabular}

penggunaan antipsikotik tipikal ini yaitu mudah menimbulkan efek samping ekstrapiramidal dan tardive dyskinesia, serta sering menyebabkan terjadinya kekambuhan (Sinaga 2007).

Data yang diperoleh menunjukkan bahwa obat yang paling banyak digunakan sebagai obat penunjang selama pengobatan skizofrenia di Instalasi Rawat Inap RSJD Atma Husada tahun 2016 adalah triheksifenidil karena obat ini merupakan salah satu obat yang sering digunakan apabila didapatkan sindroma ekstrapiramidal akibat penggunaan antipsikotik. Triheksifenidil sebagai terapi efek samping esktrapiramidal yang diinduksi oleh antipsikotik dan obat-obatan sistem saraf sentral, seperti akathisia, distonia, dan pseudoparkinsonisme (tremor, rigiditas, akinesia) dan sindroma ekstrapiramidal (EPS) (Swayami 2014). Penggunaan ajuvan terbanyak kedua yaitu diazepam sebagai anti ansietas karena diazepam merupakan kelompok obat transquillizer yang ditambahkan untuk mengobati episode akut pada penderita skizofrenia, serta mampu memberikan efek sedasi dan anxiolitik (Wiffen et al 2007).

Berdasarkan data yang diperoleh, diketahui sebanyak 125 resep antipsikotik baik tunggal maupun kombinasi diberikan kepada 94 pasien yang ditetapkan sebagai sampel. Perbedaan jumlah pasien dan jumlah resep yang terdapat dalam penelitian ini dikarenakan beberapa pasien mendapatkan lebih dari satu resep antipsikotik selama masa perawatannya, hal ini mengingat pengobatan skizofrenia merupakan pengobatan jangka panjang dan memiliki beberapa tahapan pengobatan yang disesuaikan dengan kondisi dan keadaan pasien.

Tabel 4. Persentase penggunaan obat antipsikotik tunggal dan kombinasi pada pasien skizofrenia di Instalasi Rawat Inap RSJD Atma Husada Mahakam Samarinda pada tahun 2016.

\begin{tabular}{lll}
\hline \multicolumn{1}{c}{ Penggunaan Obat } & Jumlah Resep & \multicolumn{1}{c}{ Persentase (\%) } \\
\hline Tunggal & 73 & 58,40 \\
Kombinasi 2 obat antipsikotik & 50 & 40,00 \\
Kombinasi 3 obat antipsikotik & 2 & 1,60 \\
\hline Total: & $\mathbf{1 2 5}$ & $\mathbf{1 0 0 , 0 0}$ \\
\hline
\end{tabular}

Sumber: Data sekunder yang telah diolah (2018). 
Tabel 5. Persentase penggunaan obat antipsikotik tunggal pada pasien skizofrenia di Instalasi Rawat Inap RSJD Atma Husada Mahakam Samarinda pada tahun 2016

\begin{tabular}{cccc}
\hline Golongan Obat & Obat Antipsikotik yang Digunakan & Jumlah Resep & Persentase (\%) \\
\hline Tipikal & Chlorpromazine & 4 & 5,48 \\
Tipikal & Fluphenazine & 1 & 1,37 \\
Tipikal & Haloperidol & 39 & 53,42 \\
Tipikal & Trifluopherazine & 4 & 5,48 \\
Atipikal & Aripiprazole & 1 & 1,37 \\
Atipikal & Clozapine & 6 & 8,22 \\
Atipikal & Olanzapine & 1 & 1,37 \\
Atipikal & Risperidone & 17 & 23,29 \\
\hline & Total: & $\mathbf{7 3}$ & $\mathbf{1 0 0 , 0 0}$
\end{tabular}

Sumber: Data sekunder yang telah diolah (2018)

Data yang diperoleh menunjukkan bahwa penggunaan antipsikotik terbanyak adalah dengan pemakaian tunggal karena penggunaan antipsikotik tunggal merupakan pengobatan yang disarankan berdasarkan algoritma terapi dan termasuk dalam beberapa tahap pengobatan skizofrenia. Penggunaan secara tunggal antipsikotik disarankan pada tahap pertama, kedua, ketiga, dan kelima pada pengobatan skizofrenia (Argo et al 2008). Penggunaan kombinasi antipsikotik akan menghasilkan target reseptor yang bervariasi dan lebih besar sehingga dapat meningkatkan khasiat antipsikotik dengan meningkatnya antagonis reseptor D2 dopaminergik secara aditif dan diharapkan dapat mengurangi efek samping yang terkait dengan dosis masing-masing obat (Roh et al 2010).

Data pada tabel 5 menunjukkan bahwa penggunaan antipsikotik tunggal pada pasien skizofrenia di Instalasi Rawat Inap RSJD Atma Husada Mahakam Samarinda pada tahun 2016 yang terbanyak adalah haloperidol yang merupakan antipsikotik generasi pertama karena haloperidol merupakan obat yang paling utama pada penatalaksanaan semua tipe skizofrenia (Tan \& Rahardja 2015). Haloperidol merupakan pilihan utama pada terapi tunggal pasien skizofrenia di Instalasi Rawat Inap RSJD Atma Husada Mahakam Samarinda pada tahun 2016 karena haloperidol merupakan salah satu obat turunan butiroferon yang tersedia dalam bentuk generik dan parenteral. Antipsikotik golongan butiroferon ini cenderung lebih kuat dan lebih sedikit menimbulkan efek otonom namun efek ekstrapiramidalnya lebih besar (Katzung 2012).

Tabel 6 menunjukkan kombinasi penggunaan 2 obat antipsikotik yang terdapat

Tabel 6. Persentase penggunaan kombinasi 2 obat antipsikotik pada pasien skizofrenia di Instalasi Rawat Inap RSJD Atma Husada Mahakam Samarinda pada tahun 2016

\begin{tabular}{lcc}
\hline \multicolumn{1}{c}{ Obat Antipsikotik yang Digunakan } & Jumlah Resep & Persentase (\%) \\
\hline Clozapine-Haloperidol & 19 & 38,00 \\
Clozapine-Olanzapine & 1 & 2,00 \\
Clozapine-Risperidone & 15 & 30,00 \\
Clozapine-Trifluopherazine & 2 & 4,00 \\
Haloperidol-Chlorpromazine & 6 & 12,00 \\
Haloperidol-Olanzapine & 1 & 2,00 \\
Haloperidol-Risperidone & 4 & 8,00 \\
Chlorpromazine-Risperidone & 2 & 4,00 \\
\hline Total: & $\mathbf{5 0}$ & $\mathbf{1 0 0 , 0 0}$ \\
\hline
\end{tabular}

Sumber: Data sekunder yang telah diolah (2018) 
Tabel 7. Persentase penggunaan kombinasi 3 obat antipsikotik pada pasien skizofrenia di Instalasi Rawat Inap RSJD Atma Husada Mahakam Samarinda pada tahun 2016

\begin{tabular}{lll}
\hline Obat Antipsikotik yang Digunakan & Jumlah Resep & Persentase (\%) \\
\hline Chlorpromazine-Risperidone-Clozapine & 1 & 50,00 \\
Haloperidol-Risperidone-Clozapine & 1 & 50,00 \\
\hline Total: & $\mathbf{2}$ & $\mathbf{1 0 0 , 0 0}$ \\
\hline
\end{tabular}

Sumber: Data sekunder yang telah diolah (2018).

di Instalasi Rawat Inap RSJD Atma Husada Mahakam Samarinda pada tahun 2016, dimana kombinasi terbanyak diperoleh dari kombinasi Clozapine-Haloperidol, yang merupakan salah satu kombinasi antipsikotik tipikal-atipikal. Clozapin sendiri dapat mengatasi gejala positif, gejala negatif dan kognitif tanpa menyebabkan gejala ekstrapiramidal, disamping itu obat ini dapat mengurangi depresi dan keinginan untuk bunuh diri. Clozapin juga digunakan untuk pasien yang berulang kali mendapatkan terapi tetapi tidak mendapatkan pengurangan gejala yang memadai dan pada terapi yang gagal dengan menggunakan obat lain (Stroup et al 2009). Clozapin telah terbukti memiliki khasiat yang unggul dalam mengurangi perilaku bunuh diri dan efektif dalam mengobati gejala positif dan negatif pada pasien dengan skizofrenia yang sulit disembuhkan (Bruno et al 2015).

Data yang diperoleh (Tabel 7) menunjukkan bahwa kombinasi 3 antipsikotik diberikan sebanyak dua resep, yaitu kombinasi ChlorpromazineRisperidone-Clozapine dan kombinasi Haloperidol-Risperidone-Clozapine.

Haloperidol dan chlorpromazine memiliki mekanisme kerja sebagai antagonis reseptor D2 dan D3 yang merupakan antipsikotik tipikal yang mampu mengatasi gejala positif pada pasien skizofrenia, tetapi kurang efektif dalam mengatasi gejala negatif (Ren et al 2013). Haloperidol merupakan antagonis reseptor D2 paling kuat tetapi efek terhadap sistem otonom, efek antikolinergik dan efek samping sedatif lemah, sedangkan chlorpromazine bekerja pada beberapa reseptor seperti reseptor dopamin, muskarinik, kolinergik, adrenergik (a1) dan histaminergik (H1) serta memiliki efek sedatif kuat yang dapat mengatasi gejala.

Penggunaan chlorpromazine dapat menyebabkan pasien mengalami peningkatan perasaan sulit bergaul dalam kehidupan sosial, dan merasa khawatir terhadap masa depan (Fujimaki et al 2012). Risperidone dianjurkan untuk psikosis skizofrenia kronis untuk menangani gejala negatif (Tan \& Rahardja 2015), sedangkan clozapine bekerja pada beberapa reseptor neurotransmitter seperti reseptor 5-HT1A dan 5-HT2, D1 dan D2, histamin 1 dan adrenergik (a1 dan a2) sehingga memiliki efek terapeutik dalam mengatasi gejala kognitif dan negatif seperti kemampuan dalam bersosialisasi pada pasien skizofenia (Ren et al 2013). Namun antipsikotik atipikal (clozapine) memiliki harga yang lebih mahal dibandingkan dengan antipsikotik tipikal (chlorpromazine dan

Tabel 8. Persentase kerasionalan penggunaan antipsikotik pada pasien skizofrenia di Instalasi Rawat Inap RSJD Atma Husada Mahakam Samarinda pada tahun 2016 berdasarkan ketepatan indikasi, ketepatan pemilihan obat, ketepatan pasien, dan kesesuaian dosis

\begin{tabular}{lcccc}
\hline \multicolumn{1}{c}{ Kategori } & $\begin{array}{c}\text { Jumlah obat yang } \\
\text { diresepkan }\end{array}$ & Tepat & Tidak tepat & Persentase (\%) \\
\hline Tepat indikasi & 125 & 125 & 0 & 100,00 \\
Tepat pemilihan obat & 125 & 119 & 6 & 95,20 \\
Tepat pasien & 125 & 125 & 0 & 100,00 \\
Tepat dosis & 125 & 125 & 0 & 100,00 \\
\hline
\end{tabular}


haloperidol) (Hariyani et al, 2015).

Data yang diperoleh (Tabel 8) menunjukkan bahwa penggunaan antipsikotik pada pasien skizofrenia di Instalasi Rawat Inap RSJD Atma Husada Mahakam Samarinda pada tahun 2016 yang tepat indikasi adalah sebesar 125 resep $(100,00 \%)$ karena obat antipsikotik telah menjadi terapi farmakologi utama untuk skizofrenia sejak 1950-an (Ikawati 2014). Obat-obat antipsikotik merupakan obat-obat yang digunakan untuk mengatasi gejala dari psikosis seperti delusi dan halusinasi yang tampak pada skizofrenia (Baradero 2016). Pemilihan obat mengacu pada penegakan diagnosis dokter agar obat yang diberikan dapat memberikan efek terapi sesuai dengan apa yang diharapkan (Fahrul et al 2014).

Data yang diperoleh menunjukkan bahwa pemilihan obat antipsikotik pada pasien skizofrenia di Instalasi Rawat Inap RSJD Atma Husada Mahakam Samarinda pada tahun 2016 yang tepat adalah sebesar 119 resep $(95,20 \%)$ karena beberapa pasien belum mendapatkan obat antipsikotik sesuai algoritma terapi yang ada. 6 dari 94 pasien skizofrenia yang terdapat di RSJD ATMA Husada Mahakam Samarinda tersebut tidak mendapatkan terapi antipsikotik yang sesuai dengan algoritma yang digunakan peneliti dilihat dari segi tahapan pengobatan. Keenam pasien tersebut mendapatkan kombinasi dua antipsikotik generasi satu (tipikal) yaitu HaloperidolChlorpromazine dimana kombinasi kedua antipsikotik tersebut tidak terdapat dalam algoritma terapi yang digunakan peneliti.

Kombinasi dari haloperidol dan klorpromazin sangat sesuai karena cara kerja keduanya sama yaitu memblok reseptor D2 (Stahl 2003), namun kombinasi antara haloperidol dan chlorpromazin menyebabkan efek samping sindrom ekstrapiramidal (100\%), hipotensi ortostatik $(88,2 \%)$ dan efek antikolinergik yang terjadi lebih banyak jika dibandingkan dengan penggunaan tunggal masing-masing obat $(64,7 \%)$. Berdasarkan interaksi obat level serius, penggunaan bersamaan antara haloperidol dengan chlorpromazin menyebabkan keduanya mengalami meningkatkan QTc interval (Medscape 2016) yaitu suatu bentuk aritmia jantung terjadi perpanjangan interval QT sehingga dapat menyebabkan takikardi yang dapat berakibat fatal pada pasien bila tidak tertangani (Naibaho 2008). Interaksi yang terjadi secara farmakodinamik dengan efek antagonis (Setiawati et al 2002).

Data yang diperoleh menunjukkan bahwa penggunaan antipsikotik pada pasien skizofrenia di Instalasi Rawat Inap RSJD Atma Husada Mahakam Samarinda pada Tahun 2016 yang tepat pasien sebanyak 125 $(100,00 \%)$ karena berdasarkan data rekam medik pasien (pemeriksaan laboratorium, keluhan pasien, dan lain sebagainya) penggunaan antipsikotik dapat diberikan mengingat data-data tersebut masih dikatakan dalam rentang normal. Berdasarkan data laboratorium rekam medik yang dilampirkan yaitu pemeriksaan SGOT, SGPT, ureum, dan kreatinin, tidak terdapat pasien dengan peningkatan data laboratorium yang signifikan serta tidak terdapat keluhan maupun gejala toksisistas atau alergi dari pasien. Dalam penelitian ini terdapat berbagai jenis antipsikotik baik antipsikotik tipikal (generasi pertama) maupun antipsikotik atipikal (generasi kedua). Antipsikotik seperti klorpromazin, trifluoperazin, haloperidol, dan fluphenazin memiliki kontraindikasi terhadap penderita gangguan ginjal dan hati. Sedangkan antipsikotik seperti clozapine tidak boleh diberikan pada pasien dengan kelainan jantung, penyakit atau gangguan ginjal maupun hati, kehamilan, serta laktasi. Risperidone dikontraindikasikan pada ibu menyusui (laktasi), aripiprazol tidak boleh diberikan pada seseorang yang mengalami hipertensi dan pada masa laktasi. Olanzapine dikontraindikasikan pada penderita glaucoma, hipotensi, atau laktasi (BPOM RI 2017).

Data yang diperoleh menunjukkan bahwa ketepatan dosis pemberian 
antipsikotik pada pasien skizofrenia di Instalasi Rawat Inap RSJD Atma Husada Mahakam Samarinda pada Tahun 2016 yang tepat dosis yaitu sebesar $125(100,00 \%)$ karena dosis pemberian antipsikotik pada pasien skizofrenia di Instalasi Rawat Inap RSJD Atma Husada Mahakam Samarinda pada tahun 2016 secara keseluruhan sesuai range dosis yang tertera dalam literature (guideline) Texas Medication Algorithm Project Procedural Manual Schizoprenia Treatment Algorithms (2008). Dalam pengobatan untuk pasien skizofrenia, dosis yang dianjurkan adalah yang efektif dan tidak menyebabkan efek samping karena pengalaman efek samping yang tidak menyenangkan dapat mempengaruhi kepatuhan jangka panjang (Ikawati 2014). Pasien yang baru pertama kali mengalami episode skizofrenia dianjurkan untuk menggunakan antipsikotik tipikal atau antipsikotik atipikal dengan dosis yang rendah (Maramis 2009). .

Pasien memerlukan setidaknya 4 minggu dosis terapeutik dari antipsikotik (termasuk clozapine) sebelum antipsikotik tersebut dapat dikatakan tidak berespon terhadap pengobatan. Clozapine membutuhkan waktu lebih lama, hingga 3 bulan. Menilai efek maksimal dari antipsikotik dapat memakan waktu hingga 12 minggu atau lebih. Selama kekambuhan yang akut, percobaan pemberian antipsikotik kombinasi mingguan sulit untuk dipertahankan. Perlu diingat bahwa kegagalan untuk merespon suatu antipsikotik dalam 1-2 minggu sebaiknya tidak membuat antipsikotik tersebut tidak dipertimbangkan sebagai agen yang mungkin efektif untuk kedepannya. Percobaan lain mungkin bermanfaat dalam situasi tertentu (Argo et al 2008).

\section{KESIMPULAN}

Obat antipsikotik yang digunakan di RSJD Atma Husada Mahakam Samarinda meliputi: Chlorpromazine, Fluphenazine, Haloperidol, dan Trifluoperazine yang merupakan antipsikotik tipikal (generasi pertama), dan Aripiprazole, Clozapine, Olanzapine, dan Risperidone yang merupakan antipsikotik atipikal (generasi kedua). Penggunaan antipsikotik tunggal yang paling banyak digunakan adalah Haloperidol sebanyak 39 resep $(53,42 \%)$. Pada penggunaan kombinasi 2 antipsikotik yang paling banyak digunakan adalah kombinasi antara Clozapine-Haloperidol yaitu sebanyak 19 resep $(38,00 \%)$, sedangkan kombinasi 3 antipsikotik yang digunakan yaitu kombinasi antara ChlorpromazineRisperidone-Clozapine dan HaloperidolRisperidone-Clozapine masing-masing sebanyak 1 resep $(50,00 \%)$.

Penggunaan antipsikotik untuk terapi skizofrenia di Instalasi Rawat Inap RSJD Atma Husada Mahakam Samarinda tahun 2016 belum dapat dikatakan rasional dengan hasil penelitian rasionalitas penggunaan antipsikotik adalah sebagai berikut: tepat indikasi $100,00 \%$, tepat pemilihan obat $95,20 \%$, tepat pasien $100 \%$, dan tepat dosis $100 \%$ berdasarkan Guideline Texas Medication Algorithm Project Procedural Manual Schizoprenia Treatment Algorithms (2008).

\section{UCAPAN TERIMA KASIH}

Terima kasih kepada segala pihak yang terlibat dalam penelitian ini baik pihak RSJD Atma Husada Mahakam Samarinda, dosen pembimbing saya yaitu Dra. Elina Endang S, M.Si dan Meta Kartika Untari, M. Sc., Apt atas masukkan dan bimbingan yang diberikan kepada saya, serta pihak-pihak lain yang telah membantu dan mendukung penelitian ini. 


\section{DAFTAR PUSTAKA}

Argo R.T, Crismon M.L, Miller A.L, Moore T.A, Bendele S.D, Suehs B. 2008. Texas Medication Algorithm Project Procedural Manual: Schizophrenia Treatment Algorithms. The Texas Departement of State Health Service.

Arif IS. 2006. Skizofrenia: Memahami Dinamika Keluarga Pasien. Bandung: Rafika Aditama.

[Balitbang Kemenkes RI]. 2013. Riset Kesehatan Dasar; RISKESDAS. Jakarta: Balitbang Kemenkes RI.

[BMA] British Medical Association. 2009. British National Formulary Edisi 57. England: British Medical Association Royal Pharmacetical of Great Britain.

[BPOM RI] Badan Pengawan Obat Dan Makanan. 2017. Informatorium Obat Nasional Indonesi:http://pionas.pom.go.id/ioni/bab-4-sistem-saraf-pusat/42-psikosis-dangangguan-sejenis/421-antipsikosis. Diakses pada tanggal 23 Desember 2017.

Bruno V, Valiente-Gómez A, Alcoverro O. 2015. Clozapine and Fever: A Case of Continued Therapy with Clozapine. Clinical Neuropharmacology, 38(4), 151-153.

Dipiro JT, Wells BG, Schwinghammer TL, Dipiro CV. editor. 2015. Pharmacotherapy A Pathopysiologic Approach. Ed ke-9. New York: McGraw-Hill.

Fahrul, Mukaddas A, Faustine I. 2014. Online Jurnal of Natural Science. Rasionalitas Penggunaan Antipsikotik pada Pasien Skizofrenia di Instalasi Rawat Inap Jiwa RSD Madani Provinsi Sulawesi Tengah Periode Januari-April 2014., Vol.3: 18-29. Untad 2014.

Fujimaki KT, Takahashi S, Morinobu. 2012. Association of Typical versus Atypical Antipsychotics with Symptoms and Quality of Life in Schizophrenia. Influence of Antipsychotics in Schizophrenia. 7: 110.

Hariyani, Yuliastuti F, Kusuma T.M. 2015. Pharmaciana. Pola Pengobatan Pasien Schizophrenia Program Rujuk Balik di Puskesmas Mungkid Periode Januari-Juni 2014., Vol. 6 No.1, 2016: 63-70. Universitas Muhammadiyah Magelang.

Hawari D. 2014. Skizoprenia Pendekatan Holistik (Bpss) Bio-Psiko-Sosial-Spiritual. Edisi 3. Jakarta: Badan Penerbit Fakultas Kedokteran Universitas Indonesia.

Ikawati Z. 2014. Farmakoterapi Penyakit Sistem Syaraf Pusat. Yogjakarta: Bursa Ilmu.

Katzung BG. 2012. Farmakologi Dasar dan Klinik. Edisi 10. Jakarta: Penerbit Buku Kedokteran EGC.

[Kemenkes RI] Kementerian Kesehatan Republik Indonesia. 2011. Modul Penggunaan Obat Rasional.

Maramis W.F. 2009. Catatan Ilmu Kedokteran Jiwa Edisi 2. Surabaya: Airlangga University Press. 
Medscape. 2016. Drug Interaction Checker [WWW Document]. Online. URL http://reference.medscape.com/druginteractionchecker.

Mueser KT, Dilip VJ. 2008. Clinical Handbook of Schizophrenia. The Guilford Press, New York.

Naibaho D. 2008. Hubungan Interval QTc Memanjang dengan Derajat Disfugsi Hati. Universitas Sumatra Utara.

Ren YH, Wang, Xiao L. 2013. Improving Myelin Oligodendrocyte Related Dysfunction: A New Mechanism of Antipsychotics in The Treatment of Schizophrenia. International Journal of Neuropsychopharmacology. 16:691-700.

Roh MS, Jeon HJ, Kim H, Han SK, dan Hahm BJ. 2010. The Prevalence and Impact of Depression among Medical Students: A Nationwide Cross Section Study in South Korea. Acadmed 2010; 85(8); 1384-90.

Seeman MV. 2004. Gender Differences in the Prescribing of Antipsychotic Drugs. Am J Psychiatryn 161:1324-1333.

Setiawati A, Zunilda, SB, Setiabudy R. 2002. Pengantar farmakologi. Farmakol. dan Ter. Jakarta Bagian Farmakologi. Fakultas Kedokteran. Universitas Indonesia. 18-19.

Sinaga BR. 2007. Skizofrenia dan Diagnosis Banding. Jakarta: Balai Penerbit FKUI.

Stahl SM. 2003. Describing an atypical antipsychotic: receptor binding and its role in pathophysiology. Prim Care Companion J Clin Psychiatry, 2003; 5 (3): 9-13.

Stroup T.S, Lieberman J.A, McEvoy J.P, Davis S.M, Swartz M.S, Keefe R.S \& CATIE Investigator. 2009. Results of Phase 3 of The CATIE Schizophrenia Trial. Schizophrenia research, 107(1), 1-12.

Swayami IGAV. 2014. Aspek Biologi Triheksifenidil di Bidang Psikiatri. Program Pendidikan Dokter Spesialis-1 Psikiatri, Fakultas Kedokteran Universitas Udayana: Rumah Sakit Umum Pusat Sanglah Denpasar.

Tan HT dan Rahardja K. 2015. Obat-Obat Penting Edisi 7. Jakarta: Elex Media Komputindo.

[WHO] World Health Organization. 2011. The World Medicine Situation 2011. 3th Edition. Rational Use of Medicine, Geneva.

Wiffen P, Mitchell M, Snelling M. 2007. Oxford Handbook of Clinical Pharmacy, Large Medical Book, New York, 97. 